\title{
IFPR
}

\section{DETERMINANTS OF AGRICULTURAL MACHINERY ADOPTION INTENSITIES IN GHANA}

\section{HIROYUKI TAKESHIMA, YANYAN LIU}

\section{I} ncreased capital use in agriculture, including mechanization, is considered an integral process of agricultural transformation. Despite some recent emergence of medium-to-large scale farmers in SSA, as well as labor-movement out of agricultural sector (particularly youths), smallholders without substantial mechanization have remained the majority in the agricultural sector in countries like Ghana. Globally, mechanization has often been associated with large-scale farming given the complementarity between machine and land. The experiences in Asia in the last few decades, however, suggest that mechanization may grow even among smallholders before they transition into larger-scale farmers. These experiences have prompted the need to understand better how mechanization may be adopted by smallholders for whom the scope for exploiting complementarity between mechanization and land is limited.

We test the hypotheses that high-yielding technologies, which potentially raise returns to more intensive farm power use, are important drivers of adoptions of agricultural mechanization among smallholders at both extensive and intensive margins. We do so using the three rounds of repeated cross-sectional, nationally representative data (Ghana Living Standard Surveys (GLSS) 2006, 2013, 2017), as well as unique tractor-use data in Ghana collected by IFPRI and Savannah Agricultural Research Institute (IFPRI-SARI data), and multi-dimensional indicators of agroclimatic similarity with plant-breeding locations.

\section{HIGH YIELDING VARIETIES AND MECHANIZATION DEMAND: POTENTIAL LINKAGES}

High-yielding varieties tend to respond more positively to increased farm power use involved with more intensive land preparation. They often respond better to nutrient uptake (for example, dwarf varieties are less likely to lodge from grain growth resulting from nutrient absorption), and thus to tillage that brings nutrients from deep soil to surface. Compared to traditional varieties, highyielding varieties may have lower seed vigor, weed competitiveness, and, thus, may respond well to intensive tillage to kill weed seeds in the soil. In Asia, improved varieties often led to increased returns to tillage power per unit of area, which led to increased demand for farm power per unit of area. For smallholders with limited scope for exploiting complementarity between machine and land, high-yielding technologies that raise returns to farm-power use per unit of land may be the primary source of demand for mechanization.

\section{KEY DESCRIPTIVE PATTERNS \\ Machine use varies at intensive margins}

Adoptions of modern agricultural technologies can vary not only at extensive margins but also intensive margins. This is also the case for agricultural machinery. For example, spending for agricultural machine rental by adopting households vary considerably across farm households (Figure 1, based on GLSS).

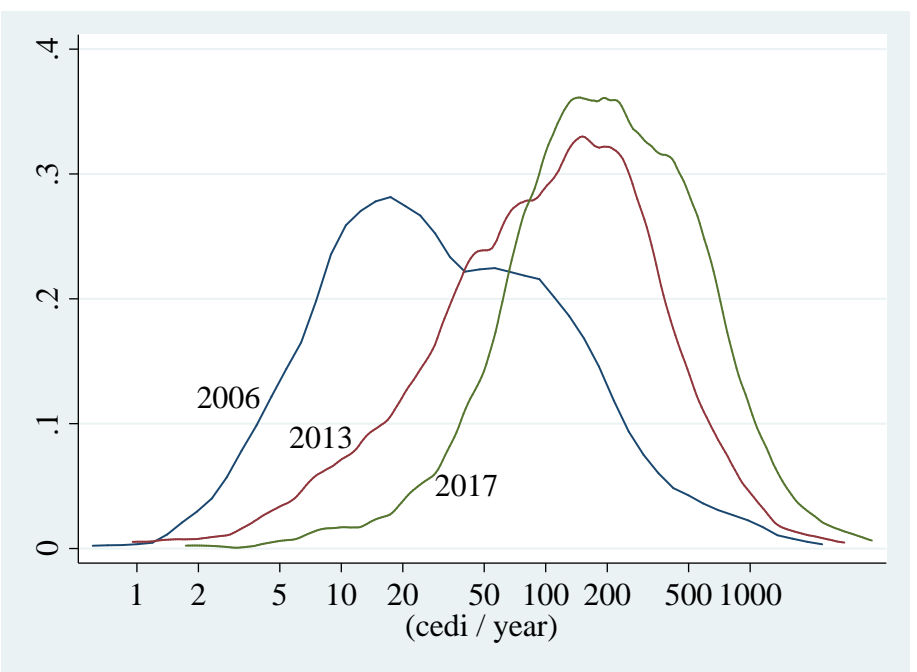

Figure 1: Variations in equipment rental intensity Source: GLSS.

Among IFPRI-SARI data, the intensity of tillage and/or harrowing by tractors on rice plots also vary across households (Table 1). While second-plowing and harrowing are less common compared to the first plowing, a fraction of rice producers use them. 
Table 1. Common use of tractors for rice by operations

\begin{tabular}{lrrrrr}
\hline Operations & $\begin{array}{c}\text { \% doing } \\
\text { this opera- tractors or } \\
\text { tion }\end{array}$ & $\begin{array}{c}\text { \% using } \\
\text { animals }\end{array}$ & $\begin{array}{r}\text { \% using } \\
\text { tractors }\end{array}$ & $\begin{array}{c}\text { \% hiring in } \\
\text { tractors }\end{array}$ & Expense \\
\hline First Plowing & 92 & 78 & 69 & 42 & 90 \\
Second Plowing & 13 & 13 & 11 & 5 & 14 \\
Harrowing & 14 & 14 & 13 & 5 & 13 \\
Planting & 97 & 9 & 8 & 3 & 8 \\
Fertilizer application & 69 & 0 & 0 & 0 & 0 \\
Carrying harvest & 98 & 4 & 4 & 3 & 44 \\
\hline
\end{tabular}

Source: Authors based on IFPRI-SARI data.

The intensive margins of machinery adoptions (machine use per unit of land) is one aspect of the gap between smallholders in Asia and African countries like Ghana. Raising such intensity can potentially induce more hiring-service providers to smallholders' farms, partly overcoming market imperfections due to accessibility to hiring-service.

\section{Cross-districts service provisions}

Figure 1 illustrates the districts where interviewed tractorowners in IFPRI-SARI data are located, and all districts where they provided hiring services in 2013. Although a significant share of service provisions are still concentrated in home districts, there are also active cross-district movements of these service providers. Understanding what drives the locations decisions is thus important.
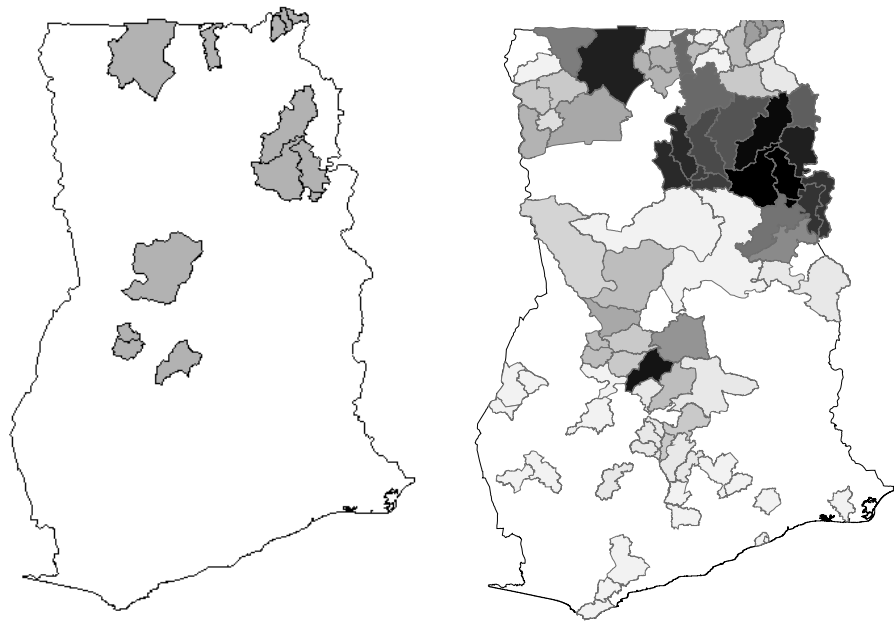

(a) Districts of interviewed tractor owners

(b) Districts where interviewed tractor owners provide services (darker color $=$ indicated by more interviewed tractor owners)

Figure 1. Districts where interviewed tractors provided services (2013) Source: IFPRI-SARI Data.

\section{Spillover potential of high-yielding varieties}

Spillover potentials of high-yielding varieties developed by Public-sector Plant Breeding (PB), depend on the similarity of agroclimatic conditions between such PB locations, and conditions where individual smallholders are located (Agroclimatic Similarity).

\section{Agroclimate: Principal components}

Quantifying the Agroclimatic Similarity requires characterizing the multi-dimensional nature of agroclimatic conditions. To do so, we construct Principal Components (PC) of agroclimatic conditions, based on several agroclimatic parameters (rainfall, wind, soil characteristics, topographies, etc.) (Table 2). The first PC account for 28 percent of the overall variations in agroclimatic conditions, and the first 3 and 6 PCs account for 54 percent and 81 percent, respectively. Analyses based on 6 PCs can therefore well represent the overall agroclimatic conditions in our sample.

Table 2. Principal components of agroclimatic conditions

\begin{tabular}{lrrrrrr}
\hline Agroclimatic parame- & \multicolumn{6}{c}{ Eigenvectors } \\
\cline { 2 - 7 } ters & 1 & 2 & 3 & 4 & 5 & 6 \\
\hline Rainfall & -.38 & -.17 & .01 & .10 & .22 & -.01 \\
Wind & .29 & .12 & -.26 & .34 & -.28 & -.07 \\
Drainage (poor) & .31 & .11 & .40 & .05 & -.06 & -.26 \\
Drainage (excessive) & -.11 & -.23 & .27 & .40 & -.17 & .58 \\
Sodicity of soil & .34 & .09 & -.01 & .11 & .49 & .34 \\
Salinity of soil & .32 & .18 & -.10 & .31 & .38 & .19 \\
Coarse soil (\%) & .28 & -.21 & -.26 & -.16 & -.14 & .38 \\
Fine soil (\%) & .20 & .13 & .50 & .28 & -.08 & -.28 \\
Organic content & -.32 & -.10 & .29 & .40 & .15 & .05 \\
pH of soil & .21 & .29 & .38 & -.42 & .04 & .22 \\
Elevation & -.27 & .26 & .28 & -.33 & -.07 & .36 \\
Terrain ruggedness & -.22 & .54 & -.21 & .14 & .03 & .03 \\
Slope & -.23 & .51 & -.15 & .10 & .17 & -.02 \\
Distance to river & .00 & .27 & -.05 & .19 & -.61 & .21 \\
& & & & & & \\
Share (\%) of variations & 28 & 42 & 54 & 65 & 74 & 81 \\
\hline Source: Authors. & & & & & &
\end{tabular}

\section{Agroclimatic Similarity with plant-breeding institutes}

Agroclimatic Similarity for each household with PB locations is defined for each of 6 PCs of agroclimatic conditions. It is based on the absolute differences in PCs between household locations, and PB locations with the most similar agroclimatic conditions (smallest difference in corresponding PC (Table 3). With 6 AS indices for each household, we capture the Agroclimatic Similarity considering multi-dimensional aspects of agroclimatic conditions.

Table 3. Agroclimatic similarity indices based on principal components of agroclimatic conditions

\begin{tabular}{|c|c|c|c|c|c|c|c|c|}
\hline \multirow[t]{2}{*}{$\begin{array}{l}\text { Hous } \\
\text { ehold }\end{array}$} & \multirow[t]{2}{*}{$P C$} & \multirow[t]{2}{*}{$\begin{array}{c}\text { PC } \\
\text { score }\end{array}$} & \multicolumn{5}{|c|}{$\begin{array}{l}\text { Negative value of absolute difference with PC } \\
\text { Score with PB locations }\end{array}$} & \multirow{2}{*}{$\begin{array}{l}\text { AS for cor- } \\
\text { responding } \\
\text { PC } \\
(\max =0)\end{array}$} \\
\hline & & & 1 (Accra) & $\begin{array}{c}2 \text { (Ache- } \\
\text { rensua } \\
\text { Mabang) }\end{array}$ & $\begin{array}{c}3 \\
\text { Adidome) }\end{array}$ & $\ldots$ & 19 (Wa) & \\
\hline 1 & 1 & -2.17 & -4.12 & -0.80 & -4.09 & $\ldots$ & -2.32 & -0.80 \\
\hline 1 & 2 & -4.15 & -2.62 & -0.27 & -1.79 & & -4.27 & -0.27 \\
\hline 1 & $\vdots$ & $\vdots$ & $\vdots$ & $\vdots$ & $\vdots$ & $\cdots$ & $\vdots$ & $\vdots$ \\
\hline 1 & 6 & 3.95 & -2.93 & -4.05 & -6.50 & $\ldots$ & -3.19 & -2.93 \\
\hline 2 & 1 & 0.02 & -1.93 & -1.38 & -1.91 & 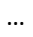 & -0.13 & -0.13 \\
\hline$\vdots$ & $\vdots$ & $\vdots$ & $\vdots$ & $\vdots$ & $\vdots$ & $\ldots$ & $\vdots$ & $\vdots$ \\
\hline
\end{tabular}

Source: Authors.

AS = Agroclimatic Similarity: $\mathrm{PC}=$ principal component: $\mathrm{PB}=$ Plant Breeding .

Figure 2 illustrates simple relations between agricultural machinery adoption rates and the Agroclimatic Similarity (first three PCs) in 2006, 2013 and 2017. The two variables are positively associated in general and this pattern has become more 

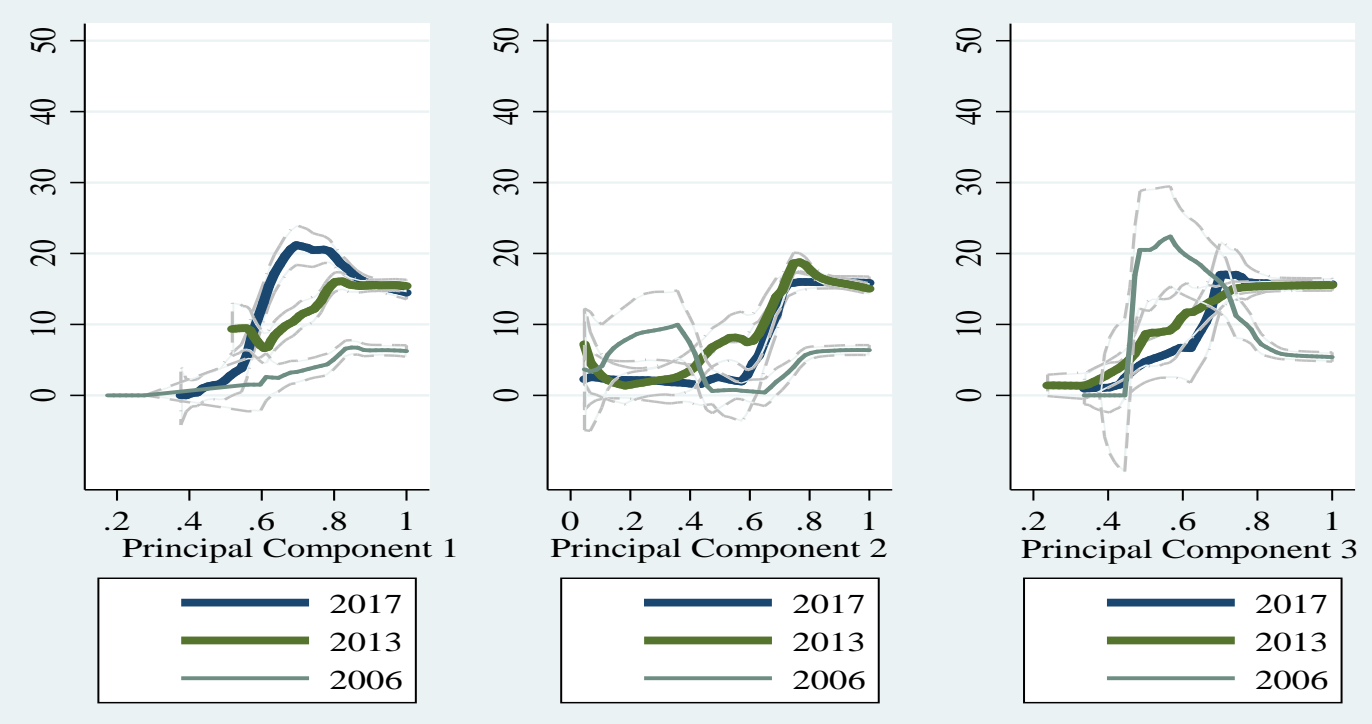

Figure 2. Agroclimatic similarity with plant breeding locations, and machine adoption probability (\%)

Source: Authors.

Note:

Vertical axis $=$ adoption probability (\%); Horizontal axis = agroclimatic similarity (standardized between $0-1$ )

Dashed lines indicate 95\% confidence intervals.

pronounced in 2013 and 2017 than in 2006. These hold for multiple-dimensions of agroclimatic conditions.

\section{RESULTS}

\section{Effects of Agroclimatic Similarity on mecha-} nization adoptions at extensive and inten-

\section{sive margins}

Table 4 summarizes the estimated effects of 6 PCs of Agroclimatic Similarity on agricultural equipment rental at both extensive and intensive margins. Some Agroclimatic Similarity-PCs are statistically significantly positive while none are statistically significantly negative. Agroclimatic Similarity is generally positively associated with the probability of adopting machines through rental, and rental spending upon renting, even when considering the multi-dimensional nature of the agroclimatic conditions. Furthermore, the positive effects of Agroclimatic Similarity on agricultural equipment rental have thus been strengthened in 2013 and 2017 compared to 2006.

Table 4. Effects of Agroclimatic Similarity on machine rental

\begin{tabular}{|c|c|c|c|c|c|c|}
\hline \multirow{3}{*}{$\begin{array}{l}\text { Agroclimatic Similarity } \\
\text { based on each Princi- } \\
\text { pal Component (PC) }\end{array}$} & \multicolumn{4}{|c|}{$\begin{array}{l}\text { Extensive margins: Whether to rent } \\
\text { in agricultural machines }\end{array}$} & \multirow{2}{*}{\multicolumn{2}{|c|}{$\begin{array}{c}\text { Intensive mar- } \\
\text { gins: expendi- } \\
\text { ture / ha } \\
\text { Truncated re- } \\
\text { gression }(\lambda= \\
0.5) \\
\end{array}$}} \\
\hline & \multicolumn{2}{|c|}{$\begin{array}{l}\text { Linear probability } \\
\text { model }\end{array}$} & \multicolumn{2}{|c|}{ Probit } & & \\
\hline & Coef. & Std.err & Coef. & Std.err & Coef. & Std.err \\
\hline PC 1 & -.032 & $(.020)$ & -.019 & $(.039)$ & .000 & $(.031)$ \\
\hline PC 2 & -.016 & $(.013)$ & -.021 & (.029) & .019 & $(.052)$ \\
\hline PC 3 & $.055 * * *$ & $(.021)$ & $.077^{* *}$ & $(.036)$ & $.074 * *$ & $(.033)$ \\
\hline PC 4 & -.034 & $(.023)$ & -.036 & $(.036)$ & -.057 & $(.054)$ \\
\hline PC 5 & .029 & $(.020)$ & $.065 * *$ & $(.032)$ & -.003 & $(.036)$ \\
\hline PC 6 & -.006 & $(.019)$ & .014 & $(.034)$ & -.018 & $(.034)$ \\
\hline PC 1 *year 2013/2017 & $.040 * * *$ & $(.012)$ & $.086^{* *}$ & $(.034)$ & & \\
\hline PC 2 *year 2013/2017 & .008 & $(.009)$ & .008 & $(.025)$ & & \\
\hline PC 3 *year 2013/2017 & $.055^{* * *}$ & $(.016)$ & $.117^{* * *}$ & (.036) & & \\
\hline PC 4 *year 2013/2017 & .004 & $(.012)$ & -.010 & $(.030)$ & & \\
\hline PC 5 *year 2013/2017 & -.005 & $(.014)$ & -.033 & (.033) & & \\
\hline
\end{tabular}

\begin{tabular}{|c|c|c|c|c|}
\hline $\begin{array}{l}\text { PC } 6 \text { *year 2013/2017 } \\
\text { Other controls }\end{array}$ & $\begin{array}{c}.004 \\
\text { Included }\end{array}$ & $(.012)$ & .002 & $(.032)$ \\
\hline Obs. & 16,517 & & 16,517 & 2,424 \\
\hline
\end{tabular}

Similarly, Table 5 shows that yield has statistically significantly positive effects on agricultural equipment rental at both extensive and intensive margins. Here, none of the year-interaction terms is significant, suggesting that, even in 2006, machine rental was significantly induced once high-yielding production was possible.

Table 5. Effects of yield on machine rental at both margins

\begin{tabular}{|c|c|c|c|c|c|c|}
\hline \multirow[t]{3}{*}{ Variables } & \multirow{2}{*}{\multicolumn{2}{|c|}{$\begin{array}{c}\text { Extensive margins: } \\
\text { (Whether to rent in } \\
\text { agricultural ma- } \\
\text { chines) } \\
\text { IV linear probability } \\
\text { model }\end{array}$}} & \multicolumn{4}{|c|}{$\begin{array}{l}\text { Intensive margins: Machine expendi- } \\
\text { ture per ha }\end{array}$} \\
\hline & & & \multicolumn{2}{|c|}{$\begin{array}{l}\text { Exogenous Heck- } \\
\text { man's method }\end{array}$} & \multicolumn{2}{|c|}{$\begin{array}{l}\text { Endogenous Heck- } \\
\text { man's method }\end{array}$} \\
\hline & Coef. & Std.erra & Coef. & Std.erra & Coef. & Std.err ${ }^{a}$ \\
\hline \multicolumn{7}{|l|}{ All sample } \\
\hline In (Yield) & $1.376^{*}$ & $(.748)$ & $.202 * * *$ & $(.033)$ & $.432 *$ & (.253) \\
\hline In (Yield) & $1.105^{* * *}$ & $(.354)$ & 112 & $(.093)$ & $.584 *$ & $(.320)$ \\
\hline $\begin{array}{l}\text { In (Yield) * year } \\
2013 / 2017\end{array}$ & 1.226 & $(.966)$ & .198 & (.178) & -.365 & (.708) \\
\hline
\end{tabular}

Table 6 further shows that, among IFPRI-SARI data sample, both Agroclimatic Similarity and yield have significantly positive effects on the tractor use intensity (frequency of harrowing and tillage) on rice plots, among relatively smaller farms (owning less than 20 ha).

Table 6. Effects on tractor use intensity (frequency of harrowing, tillage) on rice plots (IFPRI-SARI data; among farmers < 20ha)

\begin{tabular}{lcccccc}
\hline $\begin{array}{l}\text { Agroclimatic Similarity } \\
\text { based on each Principal } \\
\text { Component (PC) }\end{array}$ & \multicolumn{2}{c}{$\begin{array}{c}\text { Ordinary Least } \\
\text { Squares }\end{array}$} & \multicolumn{2}{c}{ Ordered probit } & \multicolumn{2}{c}{$\begin{array}{c}\text { Two-Stage } \\
\text { Least Squares }\end{array}$} \\
\cline { 2 - 7 } & Coef. & Std.err & Coef. & Std.err & Coef. & Std.err \\
\hline PC 1 & .016 & $(.054)$ & .034 & $(.123)$ & & \\
PC 2 & $.063^{*}$ & $(.036)$ & $.136^{*}$ & $(.080)$ & &
\end{tabular}




\begin{tabular}{|c|c|c|c|c|c|}
\hline PC 3 & -.021 & $(.030)$ & -.058 & $(.066)$ & \\
\hline PC 4 & -.058 & $(.072)$ & -.134 & (.158) & \\
\hline PC 5 & $.069 *$ & $(.037)$ & $.142^{*}$ & $(.080)$ & \\
\hline PC 6 & .020 & $(.079)$ & .053 & $(.177)$ & \\
\hline In (Yield) & & & & & $.424^{*} \quad(.231)$ \\
\hline Other controls & Included & & Included & & Included \\
\hline Obs. & 385 & & 385 & & 385 \\
\hline
\end{tabular}

Yield is in fact positively affected by agroclimatic similarity with PB locations

Table 7 shows the effects of Agroclimatic Similarity on yield. Similar to the effects on mechanization adoptions, coefficients on Agroclimatic Similarity are either positively statistically significant, or insignificant, for both GLSS and IFPRI-SARI Data. These support our hypotheses that yield is in fact positively affected by the similarity of agroclimatic conditions with PB locations, which enhance spillover potentials of high-yielding varieties developed by these PB locations.

Table 7. Effects of Agroclimatic Similarity on yield

\begin{tabular}{lcccccc}
\hline Agroclimatic Simi- & \multicolumn{4}{c}{ GLSS data } & \multicolumn{2}{c}{ IFPRI-SARI data } \\
\cline { 2 - 7 } $\begin{array}{l}\text { larity Principal } \\
\text { Component (PC) }\end{array}$ & \multicolumn{2}{c}{ Whole sample } & \multicolumn{2}{c}{$<10$ ha } & \multicolumn{2}{c}{$<$ ha } \\
\cline { 2 - 7 } & Coef. & Std.err & Coef. & Std.err & Coef. & Std.err \\
\hline PC 1 & .061 & $(.064)$ & .066 & $(.066)$ & .041 & $(.080)$ \\
PC 2 & -.111 & $(.078)$ & -.105 & $(.080)$ & $.106^{* *}$ & $(.050)$ \\
PC 3 & .081 & $(.082)$ & .091 & $(.086)$ & -.067 & $(.054)$ \\
PC 4 & -.044 & $(.060)$ & -.037 & $(.061)$ & -.175 & $(.121)$ \\
PC 5 & -.138 & $(.110)$ & -.153 & $(.113)$ & -.043 & $(.060)$ \\
PC 6 & $.256^{* * *}$ & $(.087)$ & $.307 * * *$ & $(.089)$ & .033 & $(.128)$ \\
Other controls & Included & \multicolumn{3}{c}{ Included } & \multicolumn{3}{c}{ Included } \\
\hline Obs. & 12,164 & \multicolumn{3}{c}{11,541} & \multicolumn{3}{c}{385} \\
\hline \multicolumn{1}{c}{ Source: Authors' estimations. ${ }^{* * *} 1 \%$} & $* * 5 \%$ & $* 10 \%$ \\
\end{tabular}

\section{POLICY RECOMMENDATIONS}

Achieving inclusive transformation of agriculture remains crucial in countries like Ghana, where the agricultural sector faces dual-challenges of rising labor costs and persistent smallholder dominance (despite the emergence of larger farmers in certain pockets). Such transformation is expected to require increased use of agricultural machinery like tractors by smallholders. This has largely happened in Asia in the last several decades.

Ghana may be able to follow similar transformation patterns. However, many constraints still need to be removed, including technological, institutional factors. For institutional factors, the government should continue promoting custom-hiring service rather than tractor ownership as the medium for smallholders' access to machines.

For technological constraints, the government should recognize that the demand for machines including tractors must be raised not only at extensive margins (i.e., whether to use machines), but also at intensive margins (i.e., how intensively to use machines). Raising such demand intensity is critical for inducing custom-hiring service providers to serve smallholders because transactions costs are higher in serving smallholders. For one, the government needs to support the diffusion of high-yielding varieties. One way to do so may be to expand the plant-breeding locations, especially in areas that are distinct from existing plantbreeding locations in terms of agroclimatic conditions. Doing so will particularly raise demand for tractors among smallholders located in areas that share similar agroclimatic conditions with those new plant-breeding locations, for which current yield potential is low, and demand is insignificant.

Enhancing demand for machines at intensive margins is a critical complement to other conventional measures (market and trade liberalizations for machines and parts, reduced distortions in subsidies, training on machine use and maintenance, and R\&D for local manufacturing / fabrications) which have already been identified in earlier studies on agricultural mechanization in Ghana. Lastly, this approach is likely to be effective for the broader class of farms than in Asia where this is not effective for small-holders above certain thresholds (for example, our companion paper on Nepal shows that similar effects hold only for smallholders owning less 1 ha of land).

\section{We gratefully acknowledge funding support from Syngenta Foun- dation for Sustainable Agriculture and the CGIAR Research Pro- gram on Policies, Institutions, and Markets (PIM).}

INTERNATIONAL FOOD POLICY RESEARCH INSTITUTE

A member of the CGIAR Consortium | A world free of hunger and malnutrition

1201 I Street, NW | Washington, DC 20005 USA

$\mathrm{T}:+1.202 .862 .5600 \mid \mathrm{F}:+1.202 .467 .4439$

Email: ifpri@cgiar.org |www.ifpri.org

This publication has been prepared as an output from the project - mechanization process in Asia and its implication in SSA. It has not been peer reviewed. Any opinions stated herein are those of the author(s) and are not necessarily representative of or endorsed by the International Food Policy Research Institute.

Copyright C 2019 International Food Policy Research Institute. All rights reserved. To obtain permission to republish, contact ifpri-copyright@cgiar.org. 